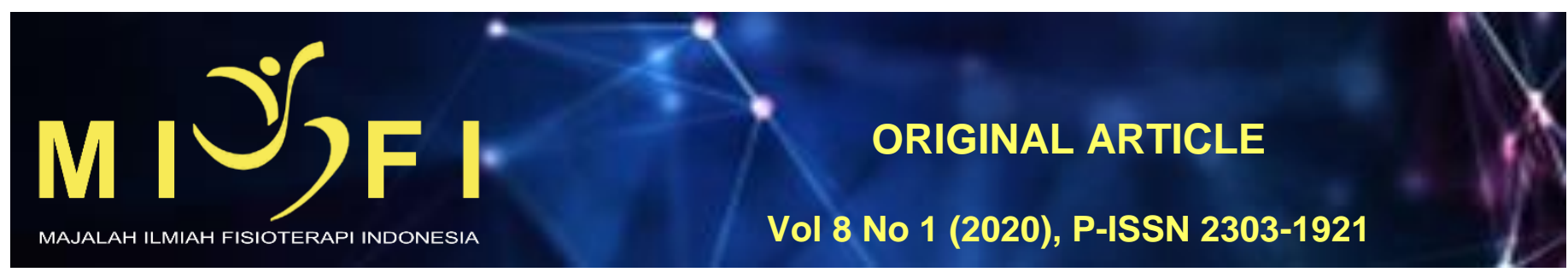

\title{
PERBEDAAN WAKTU REAKSI VISUAL BERDASARKAN TINGKAT AKTIVITAS FISIK PADA MAHASISWA KEDOKTERAN UNIVERSITAS UDAYANA
}

\author{
Ni Luh Githa Sumiati ${ }^{1}$, Ni Komang Ayu Juni Antari ${ }^{2}$, Ni Luh Nopi Andayani ${ }^{3}$, I Made Winarsa Ruma ${ }^{4}$ \\ ${ }^{1}$ Program Studi Sarjana Fisioterapi dan Profesi Fisioterapi, Fakultas Kedokteran Universitas Udayana \\ 2,3Departemen Fisioterapi, Fakultas Kedokteran Universitas Udayana \\ ${ }^{4}$ Departemen Biokimia, Fakultas Kedokteran Universitas Udayana \\ niluhgithasumiati@yahoo.com
}

\begin{abstract}
ABSTRAK
Waktu reaksi adalah interval antara permulaan stimulus dan inisiasi respon gerakan. Faktor-faktor yang mempengaruhi waktu reaksi adalah usia, jenis kelamin, penggunaan tangan dominan, intensitas rangsangan, kelelahan, olahraga, dan IMT. Penelitian ini bertujuan untuk mengetahui perbedaan waktu reaksi visual berdasarkan tingkat aktivitas fisik pada mahasiswa kedokteran Universitas Udayana. Desain penelitian yang digunakan adalah crosssectional analytic yang dilakukan pada bulan Mei 2019. Total sampel penelitian ini adalah 88 orang yang dibagi menjadi dua kelompok penelitian berdasarkan tingkat aktivitas fisik. Variabel bebas pada penelitian ini adalah tingkat aktivitas fisik dan variabel terikatnya adalah waktu reaksi visual. Hasil penelitian menunjukkan nilai $p=0,003(p<0,05)$ dengan nilai rerata waktu reaksi visual pada kelompok aktivitas fisik aktif dan kelompok aktivitas fisik kurang aktif masing masing $462,77 \pm 50,116 \mathrm{~ms}$ dan $513,36 \pm 95,757 \mathrm{~ms}$. Kesimpulan dari penelitian ini adalah terdapat perbedaan waktu reaksi visual yang signifikan berdasarkan tingkat aktivitas fisik pada mahasiswa kedokteran Universitas Udayana, dimana waktu reaksi visual pada kelompok aktivitas fisik aktif lebih cepat dibandingkan kelompok aktivitas fisik kurang aktif.

Kata Kunci: aktivitas fisik, waktu reaksi visual, mahasiswa
\end{abstract}

\section{DIFFERENCE OF VISUAL REACTION TIME BASED ON LEVEL OF PHYSICAL ACTIVITIES IN MEDICAL STUDENTS OF UDAYANA UNIVERSITY}

\begin{abstract}
The reaction time is the interval between the start of the stimulus and the initiation of the movement response. Factors that influence reaction time are age, gender, dominant hand use, intensity of stimulation, fatigue, exercise, and BMI. This study aims to determine the difference in visual reaction time based on the level of physical activity in medical students at Udayana University. The research design used was cross-sectional analytic conducted in May 2019. The total sample of this study was 88 people divided into two research groups based on the level of physical activity. The independent variable in this study is the level of physical activity and the dependent variable is the time of visual reaction. The results showed the value of $p=0.003(p<0.05)$ with the average visual reaction time in the active physical activity group and the less active physical activity group respectively $462.77 \pm 50.116 \mathrm{~ms}$ and $513.36 \pm 95.757 \mathrm{~ms}$. The conclusion of this study is that there is a significant difference in visual reaction time based on the level of physical activity in Udayana University medical students, where the visual reaction time in the active physical activity group is faster than the less active physical activity group.
\end{abstract}

Keywords: physical activity, visual reaction time, medical students 


\section{PENDAHULUAN}

Banyak orang dituntut untuk bekerja secara cepat demi tercapainya kesuksesan. Mahasiswa adalah salah satu yang memerlukan kecepatan dalam melakukan suatu pekerjaan, karena mahasiswa sering dihadapkan dengan kondisi yang memerlukan kecepatan dalam bertindak misalnya pada saat melaksanakan ujian tertulis maupun praktek yang memerlukan proses berpikir secara cepat.

Mahasiswa adalah seseorang yang sedang menempuh pendidikan pada salah satu perguruan tinggi yang terdiri dari akademik, politeknik, sekolah tinggi, institut dan universitas. ${ }^{1}$ Mahasiswa dapat dikategorikan berada pada tahap perkembangan yang usianya 18-25 tahun. ${ }^{2}$ Mahasiswa berada pada masa transisi dari remaja akhir menuju dewasa awal, dan pada masa ini terjadi penurunan aktivitas fisik yang paling nyata sepanjang rentang hidup manusia. ${ }^{3}$ Pada era globalisasi, banyak terdapat kemajuan teknologi yang memengaruhi kehidupan manusia dalam mempermudah seseorang untuk memenuhi kebutuhan hidupnya, sehingga mengakibatkan perubahan perilaku yang cenderung kurang sehat seperti kurang olahraga. ${ }^{4} \mathrm{Hal}$ ini berdampak pada aktivitas manusia yang semakin menurun.

Aktivitas fisik adalah suatu gerakan tubuh yang dihasilkan oleh otot rangka yang memerlukan pengeluaran energi. ${ }^{5}$ Aktivitas fisik dapat diklasifikasikan menjadi dua kriteria yaitu aktivitas fisik aktif dan aktivitas fisik kurang aktif. Aktivitas fisik aktif adalah individu yang melakukan aktivitas fisik berat atau sedang atau keduanya, sedangkan aktivitas fisik kurang aktif adalah individu yang tidak melakukan aktivitas fisik sedang maupun berat. ${ }^{6}$

Menurut data dari riset kesehatan dasar, Indonesia mengalami peningkatan proporsi aktivitas fisik yang kurang aktif yaitu dari 26, $1 \%$ pada tahun 2013 menjadi 33,5 \% pada tahun 2018. ${ }^{7}$ Penurunan tingkat aktivitas fisik dapat berdampak buruk bagi kesehatan karena aktivitas fisik merupakan salah satu upaya dalam menjaga kesehatan. Olahraga termasuk bagian dari aktivitas fisik. Olahraga dapat meningkatkan aliran darah dan oksigen ke otot rangka dan otak sehingga dapat mempengaruhi waktu reaksi. ${ }^{8}$

Waktu reaksi merupakan interval waktu penerimaan suatu stimulus hingga terjadinya respon motorik secara sadar. ${ }^{9}$ Terdapat tiga jenis waktu reaksi yaitu waktu reaksi sederhana, waktu reaksi kompleks dan waktu reaksi diskriminatif. Waktu reaksi juga memiliki tiga jenis stimulus yaitu visual, audiotori dan taktil. ${ }^{10}$

Kecepatan waktu reaksi diperlukan dalam pekerjaan yang memerlukan reaksi secara cepat seperti pilot, pembalap, dan tenaga medis. ${ }^{11}$ Mahasiswa kedokteran adalah calon tenaga medis yang akan dihadapkan dengan kondisi yang memerlukan kecepatan dalam bertindak, sehingga mahasiswa kedokteran penting memiliki waktu reaksi yang cepat agar terbiasa dalam menghadapi situasi dan kondisi yang memerlukan kecepatan dalam bertindak.

Terdapat penelitian yang menyebutkan bahwa mahasiswa kedokteran yang berolahraga secara teratur memiliki waktu reaksi yang lebih cepat jika dibandingkan dengan mahasiswa kedokteran yang berperilaku sedentari (sedentary lifestyles). ${ }^{12}$ Peneliti lain juga menunjukkan bahwa mahasiswa yang berolahraga secara rutin yaitu minimal $3 \times$ perminggu dengan durasi minimal 30 menit memiliki waktu reaksi yang lebih cepat dari mahasiswa yang tidak berolahraga secara rutin. ${ }^{13}$ Berdasarkan penelitian tersebut dapat disimpulkan bahwa aktivitas fisik yang aktif seperti berolahraga dapat mempengaruhi waktu reaksi seseorang menjadi lebih cepat, namun di Indonesia khususnya Bali data penelitian mengenai aktivitas fisik dan waktu reaksi masih terbatas, selain itu juga masih banyak terdapat mahasiswa yang memiliki tingkat aktivitas fisik yang rendah seperti penelitian dari Habut dkk yang mendapatkan hasil yaitu sebanyak 38,3\% mahasiswa kedokteran memiliki tingkat aktivitas fisik rendah dan 61,6\% mahasiswa memiliki tingkat aktivitas fisik yang sedang-tinggi. ${ }^{14}$

Berdasarkan pemaparan di atas, penelitian mengenai aktivitas fisik dengan waktu reaksi penting untuk dilakukan mengingat pentingnya waktu reaksi pada seseorang karena waktu reaksi dapat mempengaruhi kecepatan berpikir dan merespon seseorang sehingga waktu reaksi dapat mewakili tingkat koordinasi neuromuskular dan tingkat kognisi seseorang. ${ }^{15}$ Dalam kehidupan sehari-hari mayoritas pekerjaan menggunakan informasi dari visual ${ }^{16}$ sehingga penulis tertarik melihat perbedaan waktu reaksi visual antara aktivitas fisik aktif dengan aktivitas fisik kurang aktif pada mahasiswa kedokteran. Maka dari itu penulis mengangkat judul tentang "Perbedaan Waktu Reaksi Visual Berdasarkan Tingkat Aktivitas Fisik pada Mahasiswa Kedokteran Universitas Udayana".

\section{METODE}

Jenis penelitian yang digunakan adalah observasional analitik dengan desain studi cross-sectional. Penelitian ini dilakukan di Fakultas Kedokteran Universitas Udayana pada bulan Mei 2019. Sampel diambil dengan teknik purposive sampling yang berjumlah 88 sampel yang dibagi menjadi dua kelompok (44 kelompok aktivitas fisik aktif dan 44 kelompok aktivitas fisik kurang aktif). Kriteria inklusi dari penelitian ini adalah mahasiswa kedokteran Universitas Udayana yang berusia 18-20 tahun, IMT normal, dominan tangan kanan, dalam kondisi yang kurang lelah, dan bersedia mengisi informed consent. Kriteria eksklusi dari penelitian ini adalah mengonsumsi alkohol.

Variabel bebas (independent) dalam penelitian ini adalah tingkat aktivitas fisik dan variabel terikat (dependent) adalah waktu reaksi visual. Alat ukur yang digunakan penelitian ini adalah staturemeter untuk mengukur tinggi badan, timbangan untuk mengukur berat badan, Kuesioner Alat Ukur Perasaan Kelelahan Kerja (KAUPK2) untuk mengukur tingkat kelelahan, kuesioner Global Physical Activity Questionnaire (GPAQ) untuk mengukur tingkat aktivitas fisik dan aplikasi Human Benchmark Program untuk mengukur waktu reaksi visual. 
HASIL

Karakteristik sampel berdasarkan usia, jenis kelamin, aktivitas fisik, dan waktu reaksi visual ialah sebagai berikut.

Tabel 1. Distribusi Karakteristik Sampel Berdasarkan Usia, Jenis Kelamin dan Tingkat Aktivitas Fisik

\begin{tabular}{lcc}
\multicolumn{1}{c}{ Karakteristik } & $\begin{array}{c}\text { Frekuensi } \\
\text { (n) }\end{array}$ & $\begin{array}{c}\text { Persentase } \\
\text { (\%) }\end{array}$ \\
\hline Usia pada Kelompok Aktivitas Fisik Akif & & \\
18 tahun & 4 & 9,1 \\
19 tahun & 29 & 65,9 \\
20 tahun & 11 & 25 \\
Usia pada Kelompok Aktivitas Fisik Kurang Aktif & 3 & 6,8 \\
18 tahun & 30 & 68,2 \\
19 tahun & 11 & 25 \\
20 tahun & & \\
Jenis Kelamin pada Kelompok Aktivitas Fisik Akif & 12 & 27,3 \\
Laki-laki & 32 & 72,7 \\
Perempuan & & \\
Jenis Kelamin pada Kelompok Aktivitas Fisik Kurang Akif & 12 & 27,3 \\
Laki-laki & 32 & 72,7 \\
Perempuan & & \\
Tingkat Aktivitas Fisik & & 50 \\
Aktivitas fisik aktif & & 54 \\
Aktivitas fisik kurang aktif & 44 & 50
\end{tabular}

Berdasarkan data tabel 1 diketahui bahwa usia responden terbanyak pada kelompok aktivitas fisik aktif adalah usia 19 tahun sebanyak 29 orang (65,9\%), diikuti oleh usia 20 tahun sebanyak 11 orang (25\%) dan usia 18 tahun sebanyak 4 orang $(9,1 \%)$, sedangkan pada kelompok aktivitas fisik kurang aktif responden terbanyak yaitu usia 19 tahun sebanyak 30 orang $(68,2 \%)$, usia 20 tahun sebanyak 11 orang $(25 \%)$ dan usia 18 tahun sebanyak 3 orang $(6,8$ $\%$ ). Berdasarkan jenis kelamin pada kelompok aktivitas fisik aktif dan kurang aktif memiliki jumlah yang sama yaitu lakilaki 12 orang dan perempuan 32 orang dengan persentase masing-masing yaitu pada laki-laki $27,3 \%$ dan perempuan $72,7 \%$. Karakteristik sampel berdasarkan tingkat aktivitas fisik yaitu aktivitas fisik aktif dan kurang aktif memiliki jumlah yang sama yaitu berjumlah 44 orang dengan persentase masing-masing $50 \%$.

Tabel 2. Distribusi Karakteristik Sampel Berdasarkan Waktu Reaksi Visual

\begin{tabular}{ccc}
\hline Karakteristik & $\begin{array}{c}\text { Rerata } \\
\text { (ms) }\end{array}$ & Simpang Baku \\
\hline Waktu reaksi visual pada kelompok aktivitas fisik aktif & 462,77 & 50,116 \\
Waktu reaksi visual pada kelompok aktivitas fisik kurang aktif & 513,36 & 95,757 \\
\hline
\end{tabular}

Tabel 2. menunjukkan bahwa nilai rerata dan simpang baku waktu reaksi visual pada kelompok aktivitas fisik aktif yaitu sebesar $462,77 \pm 50,116$, sedangkan nilai rerata dan simpang baku waktu reaksi visual pada kelompok aktivitas fisik kurang aktif yaitu $513,36 \pm 95,757$.

Tabel 3. Hasil Uji Normalitas Waktu Reaksi Visual pada Kelompok Aktivitas Fisik Aktif dan Kurang Aktif

\begin{tabular}{cc}
\hline Variabel & $\mathbf{p}$ \\
\hline Kelompok aktivitas fisik aktif & 0,200 \\
Kelompok aktivitas fisik kurang aktif & 0,102 \\
\hline
\end{tabular}

Tabel 3. menunjukkan hasil uji normalitas menggunakan Kolmogorov smirnov. Berdasarkan hasil tabel 3, dapat dinyatakan bahwa persebaran data normal karena semua variabel memiliki nilai $p>0,05$.

Tabel 4. Hasil Uji Bivariat Waktu Reaksi Visual pada Kelompok Aktivitas Fisik Aktif dan Kurang Aktif

\begin{tabular}{ccll} 
& Kelompok & Kelompok & \\
Variabel & Aktivitas Fisik Aktif & Aktivitas Fisik Kurang Aktif & \\
\cline { 2 - 3 } & Rerata \pm SB & Rerata \pm SB &
\end{tabular}

Waktu Reaksi Visual (ms) $\quad 462,77 \pm 50,116 \quad 513,36 \pm 95,757 \quad 0,003$

Tabel 4. menunjukkan hasil uji parametrik yang menggunakan uji Independent T-Test. Berdasarkan hasil tabel 4 menunjukkan bahwa terdapat perbedaan waktu reaksi visual berdasarkan tingkat aktivitas fisik pada mahasiswa kedokteran Universitas Udayana dengan $p=0,003(p<0,05)$.

\section{DISKUSI}

\section{Karakteristik Sampel Penelitian}

Responden dalam penelitian ini merupakan mahasiswa kedokteran Universitas Udayana yang berusia 18-20 tahun. Data usia responden terbanyak pada penelitian ini adalah usia 19 tahun pada masing-masing kelompok. Pada usia 18-20 tahun tergolong ke dalam masa transisi dari remaja akhir menuju dewasa awal. Pada saat masa transisi dari remaja akhir menuju dewasa awal ini terjadi penurunan aktivitas fisik yang paling nyata sepanjang rentang hidup manusia. $^{3}$ 
Aktivitas fisik yang menurun dapat berdampak buruk bagi kesehatan karena aktivitas fisik merupakan salah satu upaya dalam menjaga kesehatan. Olahraga termasuk bagian dari aktivitas fisik. Olahraga dapat meningkatkan aliran darah dan oksigen ke otot rangka dan otak sehingga dapat mempengaruhi waktu reaksi. ${ }^{8}$ Waktu reaksi merupakan interval waktu penerimaan suatu stimulus hingga terjadinya respon motorik secara sadar. ${ }^{9}$

Kecepatan waktu reaksi diperlukan dalam pekerjaan yang memerlukan reaksi secara cepat dan tepat seperti pilot, pembalap, dan tenaga medis, ${ }^{11}$ oleh karena itu penting bagi mahasiswa kedokteran untuk memiliki waktu reaksi yang cepat.

Data jenis kelamin responden terbanyak pada penelitian ini adalah jenis kelamin perempuan pada masingmasing kelompok. Jumlah perempuan dan laki-laki pada masing-masing kelompok adalah sama. Jenis kelamin merupakan salah satu faktor yang dapat mempengaruhi waktu reaksi, dimana laki-laki lebih cepat dibandingkan perempuan. ${ }^{10} \mathrm{Hal}$ ini didukung oleh beberapa penelitian yaitu penelitian dari Karia dkk yang mendapatkan hasil bahwa laki-laki memiliki waktu reaksi yang lebih cepat dibandingkan perempuan. ${ }^{17}$ Penelitian dari Prabhavathi dkk juga mendapatkan hal yang sama yaitu mahasiswa kedokteran laki-laki memiliki waktu reaksi yang lebih cepat dibandingkan perempuan. ${ }^{15}$

Perbedaan waktu reaksi antara laki-laki dan perempuan dapat terjadi karena berdasarkan berbagai tingkat steroid seks selama fase siklus menstruasi yang berbeda yang memiliki efek penahan natrium dan air. Retensi garam dan air ini dapat memodifikasi konduksi aksonal. Hal itu juga dapat mengubah ketersediaan neurotransmitter pada tingkat sinaptik. Modulasi neurotransmitter ini ditambah dengan perubahan laju transmisi impuls karena fluktuasi kadar hormon mempengaruhi hubungan motorik sensorik dengan kecepatan pemrosesan di sistem saraf pusat. ${ }^{18}$

\section{Perbedaan waktu reaksi berdasarkan tingkat aktivitas fisik}

Waktu reaksi merupakan salah satu parameter fisiologi yang penting untuk mengetahui seberapa cepat respon individu terhadap suatu stimulus. Pengukuran waktu reaksi visual sering digunakan untuk mengevaluasi waktu proses pikir dan koordinasi antara sistem sensorik dan motorik. ${ }^{19}$

Pada penelitian ini pengukuran waktu reaksi visual menggunakan human benchmark program. Model aliran informasi secara sederhana dapat digambarkan sebagai berikut: stimulus-reseptor-integrator-efektor-respon. ${ }^{20}$ Stimulus visual diterima oleh reseptor cahaya di retina. Reseptor akan menghantarkan impuls rangsang ke otak melalui saraf sensorik. Otak akan mengubah impuls rangsang menjadi informasi untuk melakukan reaksi terhadap rangsang tersebut (respon). Otak akan menghantarkan impuls reaksi ke saraf motorik. Saraf ini melekat pada serabut serabut otot rangka yaitu neuromuscular junction, kemudian saraf motorik akan memerintahkan efektor untuk melakukan respon. Dalam hal ini, efektor yang dimaksud adalah otot sehingga otot bereaksi melakukan suatu gerakan. ${ }^{21}$

Hasil penelitian menunjukkan bahwa terdapat perbedaan waktu reaksi visual yang signifikan pada kelompok aktivitas fisik aktif dan aktivitas fisik kurang aktif dengan menggunakan uji Independent T-Test $(\mathrm{p}=0,003)$, dimana nilai rerata dan simpang baku waktu reaksi visual pada kelompok aktivitas fisik aktif adalah $(462,77 \pm 50,116)$ dan kelompok aktivitas fisik kurang aktif adalah $(513,36 \pm 95,757)$. Pada penelitian ini menunjukkan waktu reaksi visual yang lebih cepat pada kelompok dengan aktivitas fisik yang aktif dibandingkan dengan kelompok aktivitas fisik kurang aktif.

Penelitian ini sesuai dengan penelitian yang telah dilakukan oleh Jain dkk yang menyebutkan bahwa mahasiswa kedokteran yang berolahraga secara teratur memiliki waktu reaksi yang lebih cepat jika dibandingkan dengan mahasiswa kedokteran yang berperilaku sedentari (sedentary lifestyles). ${ }^{12}$ Penelitian dari maharani menunjukkan bahwa mahasiswa yang berolahraga secara rutin memiliki waktu reaksi yang lebih cepat dari mahasiswa yang tidak berolahraga secara rutin. ${ }^{13}$ Peneliti dari Devi dan Madhuri menunjukkan bahwa mahasiswa yang berolahraga secara teratur memiliki waktu reaksi visual yang lebih cepat dibandingkan dengan mahasiswa sedentari. ${ }^{22}$

Waktu reaksi visual lebih cepat pada kelompok aktivitas fisik yang aktif dibandingkan dengan kelompok aktivitas fisik kurang aktif dapat disebabkan karena pada saat individu melakukan aktivitas fisik yang adekuat, terjadi peningkatan kebutuhan oksigen dan otot rangka juga mengonsumsi ATP dalam jumlah yang lebih banyak. Proses tersebut menyebabkan lebih banyak darah yang teroksigenasi mengalir ke otot-otot dari tubuh dan memberikan dampak positif pada fungsi motorik. ${ }^{23}$ Olahraga juga diketahui dapat meningkatkan aliran darah dan oksigen ke otak, sehingga olahraga juga mempengaruhi waktu reaksi. ${ }^{8}$ Pada saat individu melakukan olahraga dengan level sedang hingga intens memiliki tingkat aliran darah otak yang lebih tinggi. Peningkatan jumlah aliran darah di otak ini menghasilkan peningkatan fungsi kognitif karena meningkatnya pasokan nutrisi yang diperlukan, seperti oksigen dan glukosa. ${ }^{12}$

\section{SIMPULAN}

Berdasarkan hasil penelitian yang telah dilakukan maka dapat disimpulkan bahwa terdapat perbedaan waktu reaksi visual berdasarkan tingkat aktivitas fisik pada mahasiswa kedokteran Universitas Udayana, dimana waktu reaksi visual pada kelompok aktivitas fisik aktif lebih cepat dibandingkan kelompok aktivitas fisik kurang aktif.

\section{DAFTAR PUSTAKA}

1. Hartaji, DA. Motivasi Berprestasi Pada Mahasiswa yang Berkuliah Dengan Jurusan Pilihan Orangtua. Skripsi Fakultas Psikologi Universitas Gunadarma; 2012

2. Yusuf, S. Psikologi Perkembangan Anak dan Remaja. Bandung : Remaja Rosdakarya; 2012

3. Kwan, MY, Cairney J, Faulkner, GE, Pullenayegum, EE. Physical Activity and other health-risk behaviors during the transition into early adulthood. Am J Prev Med. 2012;42(1) :14-20

4. Antari, NKAJ. Aplikasi Progressive Muscle Relaxation Terhadap Penurunan Tekanan Darah Pada Hipertensi Derajat I di Kota Denpasar. Majalah IImiah Fisioterapi Indonesia. 2016;4(1)

5. WHO. Physical Activity. 2016. Available at: http://www.who.int/topics/physical_activity/en/. [Accessed 25 Dese mber 2018] 
6. Kementrian Kesehatan RI. Riset Kesehatan Dasar. Jakarta: Badan Penelitian dan Pengembangan Kesehatan Kementerian Kesehatan RI; 2013

7. Kementrian Kesehatan RI. Hasil Utama Riskesdas 2018. 2018. Available at: http://www.depkes.go.id/resour ces/download/infoterkini/materi_rakorpop_2018/Hasil\%20Riskesdas\%202018.pdf. [Accessed 1 Januari 2018].

8. Roach, A, Lash, D, Loomis, E, Sinnen, T, Young, DM. The effects of exercise on reaction Time. University of Wisconsin-Madison; 2014

9. Senel, O, \& Eroglu, H. Correlation Between Reaction Time and Speed in Elite Soccer Players. Ankara : Gazy University; 2006

10. Kosinski, R. A Literature Review of Reaction Time. 2008. Available at: http://biae.clemson.edu [Accessed 25 November 2018]

11. Yonathan, JS. Perbandingan Efek Aromaterapi Eucalyptus (Eucalyptus Radiata) dengan Rosemary (Rosmarinus Officinalis) Terhadap Penurunan Waktu Reaksi Sederhana pada Mahasiswa Laki-laki Fakultas Kedokteran Universitas Kristen Maranatha. Skripsi Fakultas Kedokteran Universitas Kristen Maranatha; 2018

12. Jain, A, Bansal, R, Kumar, A, \& Singh, K D. A comparative study of visual and auditory reaction times on the basis of gender and physical activity levels of medical first year students. Int J Appl Basic Med Res. 2015.5(2): 124-127

13. Maharani, D. Perbedaan Waktu Reaksi Pada Mahasiswa Preklinik Profesi Dokter Fakultas Kedokteran Universitas Andalas Yang Berolahraga Rutin Dengan Yang Tidak Berolahraga Rutin. Skripsi Fakultas Kedokteran Universitas Andalas; 2017

14. Habut, MY, Nurmawan, IPS, Wiryanthini, IAD. Hubungan Indeks Massa Tubuh dan Aktivitas Fisik terhadap Keseimbangan Dinamis pada Mahasiswa Fakultas Kedokteran Universitas Udayana. Majalah IImiah Fisioterapi Indonesia 2016. 2 (1)

15. Prabhavathi, K, Hemamalini, RV, Kumar, TG, Amalraj, C, Maruthy, KN, Saravanan, A. A correlational study of visual and auditory reaction time with their academic performance among the first year medical students. National Journal of Physiology, Pharmacy and Pharmacology. 2017. 7(4).

16. Ghuntla, TP, Mehta, HB, Gokhale, PA, Shah, CJ. Influence of practice on visual reaction time. J Mahatma Gandhi Inst Med Sci. 2014.19:119-122

17. Karia, RM, Ghuntla, TP, Mehta, HB, Gokhale, PA, Shah, CJ. Effect Of Gender Difference On Visual Reaction Time : A Study On Medical Students Of Bhavnagar Region. IOSR Journal of Pharmacy. 2012.2:452- 454

18. Bruce, J, Russell, GFM. Premenstrual tension: a study of weight changes and balances of $\mathrm{Na}+$, water and potassium. Lancet. 1962. 11: 267-271

19. Gavkare, A. Auditory Reaction Time, Visual Reaction Time and Whole Body Reaction Times in Athletes. Indian Medical Gazzete; 2013

20. Dhungana, HN, Singh, S, Tripathi, P, Prakash, J, Waseem, SMA, Tiwari, N \& Sarthi, P. Visual Reaction Time and Its Relationship with Sex, Age, and BMI in Northern Indian. Journal of Medical Science and Technology. 2014. III(2) : 2319-3417.

21. Purnama, JN. Efektivitas Circulo Massage Dalam Memperbaiki Waktu Reaksi Sebagai Indikator Pemulihan Kelelahan Otot Mahasiswa Semester Vi Prodi Ikor Konsentrasi Kebugaran. Skripsi Fakultas IImu Keolahragaan Universitas Negeri Yogyakarta; 2014

22. Devi, BS, \& Madhuri, KN. Comparative study of visual and auditory reaction times on the basis of gender and physical activity levels of medical students. Med Pulse International Journal of Physiology. 2017. 4: 04-06.

23. Poels, Marielle MF, Mohammad A, Meike, V, Gabriel, P, Albert, H. Total cerebral blood flow in relation to cognitive function: The Rotterdam Scan Study." Journal of Cerebral Blood Flow and Metabolism. 2008. 28: 1652- 55. 